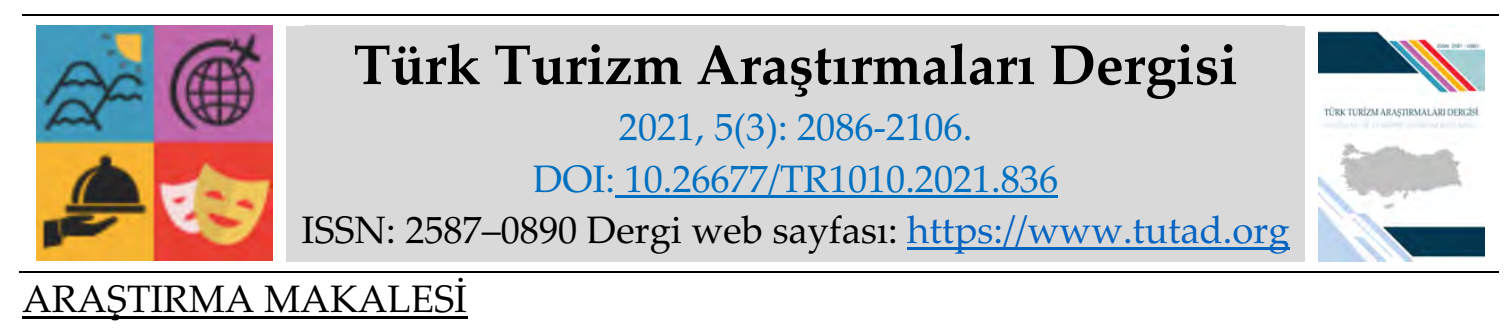

\title{
Mutfak Departmanı Personelinin Kişisel Hijyen Bilgi ve Uygulamaları: Şanlıurfa İli Konaklama İşletmelerinde Bir Uygulama
}

Nazlı ÖZMEN ARISOY, Yüksek Lisans Öğrencisi, Gaziantep Üniversitesi, Sosyal Bilimler Enstitüsü, Gaziantep, e-posta: nazlim.ozmen@gmail.com

ORCID: https://orcid.org/0000-0002-1154-4025

Dr. Öğr. Üyesi Ercan İNCE, Iğdır Üniversitesi, İktisadi ve İdari Bilimler Fakültesi, Iğdır, e-posta: ercan.ince@igdir.edu.tr

ORCID: https://orcid.org/0000-0003-4821-8140

Doç. Dr. Atınç OLCAY, Gaziantep Üniversitesi, Turizm ve Otelcilik Meslek Yüksek Okulu, Gaziantep, e-posta: olcay@gantep.edu.tr

ORCID: https://orcid.org/0000-0003-0407-5467

Öz

Turizm işletmelerinin rekabet gücünün değerlendirilmesinde ki önemli algılardan birisi de hijyendir. Hijyen, vücut bütünlüğü ve sağllğı için hastalıkları önleyici ve mevcut tehlikeleri ortadan kaldırıcı unsurları içinde barındırmaktadır. Konaklama işletmelerinin mutfak departmanında çalışan personellerin, kişisel hijyen bilgileri ve uygulamalarının yetersiz olması durumunda gıda kaynaklı hastalıklar yaygın sağlık sorunu haline gelmektedir. Bu çalışmada Şanlıurfa İl Merkezinde faaliyet gösteren otel, pansiyon, apart otel ve butik otel olmak üzere farklı statüdeki konaklama işletmelerinin mutfak departmanlarında çalışan personelin hijyen bilgisi ve uygulamalarının tespit edilmesi amaçlanmıştır. Araştırma kapsamında 17 konaklama işletmesine ulaşılarak 207 mutfak personeline anket formu uygulanmıştır. Anket formu üç bölüm ve toplam 40 sorudan oluşmaktadır. Yapılan analizler neticesinde; Araştırmaya katılan personelin temizlik açısından vücut banyosunun etkilerini, temizlik kurallarına uygun el yıkama yöntemini, diş sağlığını, burun temizliği için doğru uygulamayı bilmesine rağmen; el ve ayak tırnaklarının kesim şeklini, saç ve ayak temizliği için en doğru uygulamayı bilmediği sonucuna ulaşılmıştır.

Anahtar Kelimeler: Kişisel Hijyen, Mutfak Personeli, Konaklama İşletmesi.

Makale Gönderme Tarihi: 21.05.2021

Makale Kabul Tarihi: 01.09.2021

\section{Önerilen Atıf:}

Özmen Arısoy, N., İnce, E. ve Olcay, A. (2021). Mutfak Departmanı Personelinin Kişisel Hijyen Bilgileri ve Uygulamaları: Şanlıurfa İli Konaklama İşletmelerinde Bir Uygulama, Türk Turizm Araştırmaları Dergisi, 5(3): 2086-2106.

(C) 2021 Türk Turizm Araştırmaları Dergisi. 


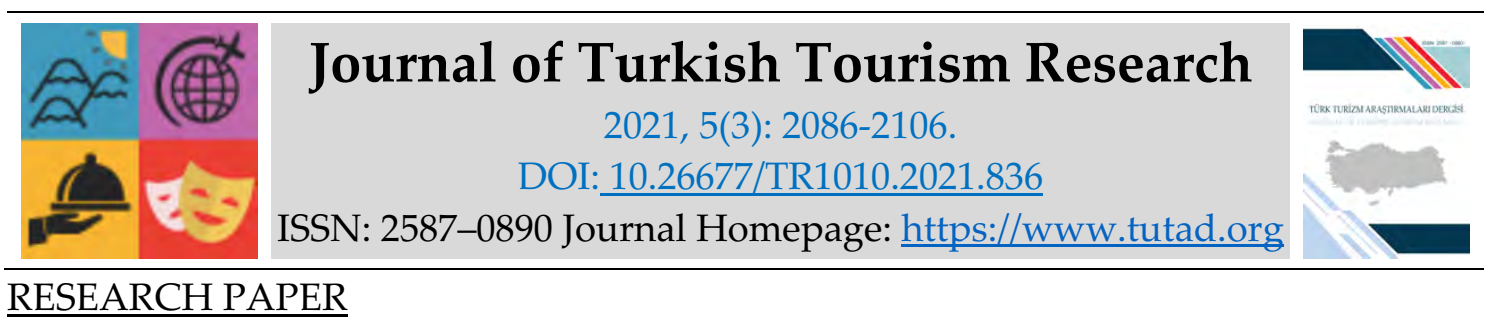

\title{
Personal Hygiene Information and Practices of Kitchen Department Staff: An Application in Şanlıurfa Province Accommodation Businesses
}

\author{
Nazlı ÖZMEN ARISOY, MSc. Student, Gaziantep University, Social Sciences Institute, Gaziantep, \\ e-mail: nazlim.ozmen@gmail.com \\ ORCID: https://orcid.org/0000-0002-1154-4025
}

Assistant Prof. Dr Ercan İNCE, Iğdır University, Faculty of Economics and Administrative Sciences, Iğdır, e-mail: ercan.ince@igdir.edu.tr ORCID: https://orcid.org/0000-0003-4821-8140

Associate Prof. Dr. Atınç OLCAY, Gaziantep University, Tourism and Hotel Management Vocational School, Gaziantep, e-mail: olcay@gantep.edu.tr ORCID: https://orcid.org/0000-0003-0407-5467

\begin{abstract}
One of the important perceptions in evaluating the competitiveness of tourism enterprises is hygiene. Hygiene includes elements that prevent diseases and eliminate existing dangers for body integrity and health. Food-borne diseases become a common health problem in the event that personnel working in the kitchen departments of accommodation businesses lack personal hygiene knowledge and practices. In this study, it was aimed to determine the hygiene knowledge and practices of the personnel working in the kitchen departments of the accommodation establishments of different statuses, including hotels, hostels, apart hotels and boutique hotels, operating in Sanliurfa City Center. Within the scope of the research, 17 accommodation establishments were reached and a questionnaire form was applied to 207 kitchen personnel. The questionnaire form consists of three parts and a total of 40 questions. As a result of the analysis made; Although the personnel participating in the research know the effects of body bath in terms of cleanliness, the method of hand washing in accordance with the hygiene rules, dental health, and the correct application for nasal cleaning; It was concluded that she did not know the way of cutting her finger and toenails and the best application for cleaning her hair and feet.
\end{abstract}

Keywords: Personal Hygiene, Kitchen staff, Hospitality Business.

Received: 21.05 .2021

Accepted: 01.09.2021

Suggested Citation:

Özmen Arısoy, N., İnce, E. and Olcay, A. (2021). Personal Hygiene Information and Practices of Kitchen Department Staff: An Application in Şanlıurfa Province Accommodation Businesses, Journal of Turkish Tourism Research, 5(3): 2086-2106.

(C) 2021 Türk Turizm Araştırmaları Dergisi. 


\section{Gíriş}

Sağlıklı yaşamak, tüm toplum ve kişilerin temel amacıdır. Bu temel amaca ulaşmak ancak kişisel hijyen kurallarına uyulması ve hijyen kuralları doğrultusunda oluşturulan yaşam alanlarının var olması ile gerçekleşebilir. Hijyen bilgi düzeyi artan tüketiciler, hijyeni bir kalite göstergesi olarak kabul etmekte ve aldıkları tüm hizmetlerin temiz, özenli ve hijyen kurallarına uygun olmasını talep etmektedir (Tayar, 2011: 6; Cömert ve Özel, 2015: 322). Müşteri memnuniyeti hijyenik ve temiz koşullarda sunulan hizmetlerle doğru orantılıdır (Sökmen, 2003: 50; Ayaz ve Aydın, 2017: 136). Yiyecek-İçecek işletmelerinde yaşamsal bir öneme sahip olan hijyen kuralları ile işletmeler sektörde başarılı olabilmektedir. Çünkü bu sektörde başarı ancak tüketiciye güvenilir, temiz, kaliteli ve sağlıklı yiyecek-içecek sunulmasıyla sağlanabilir (Sökmen, 2003: 58; Çetiner, 2010: 55; Cömert ve Özel, 2015: 322).

Turizm destinasyonu olan ülkelerin ziyaretçi sayısını etkileyen önemli unsurlardan biri hijyen kaynaklı sağlık riskidir. Bu unsur turistin satın alma sürecinde etkilidir. Destinasyonların rakiplerine karşı üstünlük elde edebilmeleri sahip oldukları sağlıklı ve güvenli ülke imajıyla doğrudan ilgilidir. Turizm ve sağlık iç içedir ve turizmde sağlık, kalite göstergesi olarak kabul edilmektedir. Bu nedenle son zamanlarda konaklama sektöründe sağlıklı, temiz ve hijyenik mal ve hizmet sunumu giderek daha fazla önem kazanmıştır (Gül vd., 2017: 23).

Konaklama işletmelerinde gıda güvenliği, konukların sağlığını koruması açısından son derece önemlidir. Çünkü otel, sadece konaklama ihtiyacını karşılanan yer olmamakla birlikte turistlerin yiyecek içecek ihtiyaçlarına da cevap verebilen hizmet kuruluşlarıdır. Hijyenik koşullara sahip olmayan bir otel mutfağı müşterilerine zarar verebileceği gibi hijyen kurallarına uyulmadığ i için meydana gelebilecek gida zehirlenmesi veya gida kaynaklı hastalıklara da zemin hazırlayabilmektedir (Sökmen, 2001:53; Bulduk, 2003:1; Gökdemir, 2003:52; Denizer, 2005:203).

Yiyecek içecek işletmelerinde ki yönetimin, hijyen uygulamalarına gerekli önemi vererek çaba göstermesi ve çalışanların bu konuda eğitilerek bilinçlendirilmesi sağlanmalıdır. Ayrıca yiyecek içecek servisinde çalışan personelin; gıda zehirlenmesine neden olan hastalıkları engellemek için gösterecekleri çabanın ahlaki ve yasal bir sorumluluk olduğunu bilmesi gerekmektedir (Cömert, 2011: 25; Kayalı, 2013: 12). Bu araştırmanın yapılmasında, turizm sektöründe faaliyet gösteren işletmelerde ki çalışanların hijyen bilgisi ve uygulamalarının bilinç düzeylerinin ölçülmesi açısından önem arz etmektedir.

\section{Hijyen Kavramının Tanımı ve Önemi}

Hijyen, bireyin yaşamını sağlıklı bir şekilde devam ettirebilmesi için yapması gereken kişisel bakımı ifade eder. Bireyin inanç, kültür, eğitim ve ekonomik düzeyi hijyen seviyesini belirleyen önemli etkenlerdir (Yasan, 2007: 31). Hijyen, insan sağlığının iyileştirilmesi uzun süre korunması için sağlıkla ilgili bilgileri ve belgeleri bir sentez halinde uygulayan bilim kompleksidir (Beyhan ve Ersin, 2001: 23).

Temizlik ve hijyen tanım olarak karıştırılan fakat birbirini tamamlayan farklı kavramlardır. Temizlik, gözle görülebilecek kirleri ortamdan uzaklaştırmak olarak açılanırken; hijyen, ortamların mikroplardan arındırılması ve sağlıklı ortamların korunması olarak tanımlanmaktadır. Temizlik, toplumsal hayatı devamı için daimî unsuru ve bireysel ve toplum sağlığının temelidir (Yılmaz Irmak, 2015; Kahveci ve Demirtaş, 2012: 51).

Yiyecek-İçecek işletmelerinde ise hijyen, personelin, çalışma ortamının, ürün ve hizmetlerin temizlik ve sağlık kurallarına uygunluğunu ifade etmektedir (Gökdemir, 2009). Hijyen, 
konaklama işletmelerinde müşteri memnuniyeti sağlanması için sağlıklı bir ortamın oluşturulması açısından oldukça önemli bir unsurdur. Her işletme hijyen konusunda maksimum güvenilirliğe ulaşmak zorundadır (Can, 2008: 28).

Tüketicilerin eğitim seviyelerinin yükselmesi hijyen alanında bilinçlenmelerine, aynı zamanda almış oldukları ürün veya hizmetlerin temiz, özenli ve sağlık açısından zararsız olması gibi beklentilerinin artmasına da neden olmuştur (Tayar, 2011: 6). Mal ve hizmet sunan işletmelerin sektördeki paylarını arttırarak daha fazla kar elde etmesinde ve iyi imaj oluşturmasında hijyen kavramı önemli hale gelmiştir (Sökmen, 2003: 58). Bireylerin kendilerini daha rahat ve güvende hissetmelerini sağlayan hijyenik uygulamalar insan hayatında sağlığın korunması ve geliştirilmesi açısından önemli bir yer tutmaktadır (Yalçın ve Özkalp, 2005; www. who.int/topics/hygiene/en/).

Hijyen, gıda hijyeni, çalışma hijyeni, çevre hijyeni ve kişisel hijyen gibi birden fazla alt başlıklarla incelenebilir. Tüm toplumu ilgilendirdiği ve sağlığın temelini oluşturduğu için kişisel hijyen en önemlilerinden biridir (Coştan,2012: 14). Kişisel bakım, sağlığın kişiler tarafından korunması ve devam ettirilmesi için bireyler tarafından başlatılan ve gerçekleştirilen faaliyetlerdir (Uzunçakmak, 2012: 17).

Kişisel bakım, kişilerin dinlenmesini, rahatlamasını sağlayarak, kişilerin kendilerine olan güvenini arttırır. Ayrıca vücudun kas gerilimini azaltmak, vücuttan salgılanan sıvıları ve mikroorganizmaları uzaklaştırmak, oluşan kötü kokuları gidermek, deri sağlığını sürdürmek ve geliştirmek gibi nedenlerle uygulanmaktadır (Şimşek, 2006: 19; Tartaç, 2007: 3; Yılmaz Irmak, 2015: 5).

Yiyecek içecek işletmelerinde, ürünlerin üretiminden sunumuna kadar her kademede görev alan personel üretimde kullanılan ekipman ve üretim alanının hijyeninden sorumludur (Soner ve Özgen, 2002: 53). Bu nedenle personelin kişisel hijyen ve temizliğine dikkat etmesi ve hijyen uygulamalarını alışkanlık haline getirmesi gerekmektedir. Dikkat edilmediği taktirde personel kaynaklı birçok mikroorganizma eller, ağız, burun, saçlar, vücut yüzeyleri ve kıyafetler kanalıyla yiyeceklere bulaşabilmektedir (Cömert, 2007: 53; Kurt, 2018: 14). Personel, hijyen konusunda sürekli bilgilendirilmeli, bilgileri verilecek eğitimlerle güncellenmelidir (Dere, 2018: 66).

\section{İLGİLİ ARAŞTIRMALAR}

Kurt (2018), çalışanların mutfak hijyen durumları üzerine görüşlerini öğrenmek amacıyla yapmış olduğu çalışmada 234 mutfak personeline anket uygulanmış ve 28 otel mutfağını hijyen değerlendirme formuna göre değerlendirmiştir. Araştırma bulguları doğrultusunda; otellerde HACCP programını uygulaması, üretim alanlarında denetimin artması, personele güvenli gıda, besin hijyeni ve sanitasyon eğitimlerinin yapılmasının önem arz ettiği sonucuna varmıştır.

Kızılcık (2016), çalışmasında Kahramanmaraş ilinde turizme hizmet sunan 7 farklı pastane işletmesinde görev alan 213 dondurma üretim personelinin hijyen ve gıda güvenliğine ilişkin bilgi ve uygulama düzeyini belirlemek amaciyla yüz yüze görüşülerek oluşturulan anket formunu uygulanmıştır. Yapılan araştırma sonucunda, personelin hijyen ve gıda güvenliğine ilişkin bilgi ve uygulama düzeyinin "yüksek" seviyede olduğu tespit edilmiştir. Personelin hijyen ve gıda güvenliğine ilişkin bilgi düzeyi üzerinde, personelin yaşının, eğitim düzeyinin, iş tecrübesinin ve hijyen güvenliği üzerine eğitim alma durumunun önemli bir etkisinin olduğu tespit edilmiştir. 
Şanlıer vd. (2016), çalışmalarında Türkiye ve Kazakistan'daki 4-5 yıldızlı otellerde çalışan 866 servis ve mutfak personelinin gıda güvenliğine ilişkin bilgi düzeylerini, tutum ve davranışlarını incelemek ve iki ülke arasındaki mevcut farklılıkları araştırmak üzere bir araştırma gerçekleştirmişlerdir. Buna göre, Türkiye ile Kazakistan arasında gıda güvenliği genel bilgi düzeyi açısından fark olmadığı ancak Türkiye'de personelin gıda güvenliğine ilişkin tutum ve davranışının daha olumlu olduğu sonucuna ulaşılmıştır. Ayrıca her iki ülkede servis ve mutfak personelinin tutumu, davranışını pozitif yönde etkilese de Kazakistan'da gıda güvenliği bilgi düzeyinin, tutum ve davranışa etkisinin, Türkiye'ye göre daha düşük kaldığı belirlenmiştir.

Çil vd. (2017), çalışmalarında gıda güvenliği bilgi, tutum ve davranışlarını incelemek üzere bir otelde farklı pozisyonlarda görev yapan 498 personele anket uygulamışlardır. Araştırma sonucunda gıda güvenliği bilgisinin gıda güvenliği davranışı üzerinde önemli bir etkisi olmadığı belirlenmiştir. İşletmelerde gıda güvenliğinin sağlanmasında dikkat edilmesi gereken önemli faktörlerin personelin eğitimi, mesleği ve deneyimi olduğu bu nedenle, personelin bu konuda gerekli eğitim ihtiyaçlarını belirlemek ve bunları dikkate alarak eğitim ve seminerler vermesi gerektiği gibi önerilerde bulunulmuştur.

Yıldırım (2014), çalışmasında Antalya il merkezinde bulunan 8 konaklama tesisinde görev yapan 124 mutfak ve 276 servis personeli olmak üzere toplam 400 personelinin iş tatmini, kişisel hijyen bilgisi ve kişisel hijyen uygulamalarını incelemiştir. Araştırma sonuçlarına göre Çalışanların kişisel hijyen bilgi düzeyleri genel olarak ortalama değerler arasında olsa da düzenli diş hekimine gitme, diş ipliği kullanma, el ve vücut temizliğinde ilk yardım ya da yaralanma gibi konularda ya da özellikle temizlik malzemelerinin ortak kullanımında hala yeterli bilincin yerleşmediği görülmektedir.

Cömert ve Ünlüönen (2013), çalışmalarında, Ankara il merkezinde bulunan dört ve beş yıldızlı toplam 17 otelin 301 mutfak çalışanına personel hijyeni hakkındaki bilgi düzeylerini ve uygulamalarını ortaya koymak amacıyla anket uygulamıştır. Yapılan analizler soncunda araştırmaya katılan otel çalışanları yaş grubuna, cinsiyete, eğitim düzeyine, mevcut işyerinde çalışma süresine, eğitim alma durumuna göre değerlendirildiğinde, personel hijyeni algı puanı açısından gruplar arasında istatistiksel olarak anlamlı fark olmadığı saptanmıştır. Otel çalışanları görevlerine, çalışma süresine ve eğitim aldıkları yere göre personel hijyeni puanları değerlendirildiğinde ise, gruplar arasında anlamlı fark olduğu saptanmıştır.

Kabacık (2013), çalışmasında Antalya, Trabzon, Çanakkale, Gaziantep ve İzmir İlinde bulunan dört yıldızlı ve beş yıldızlı otel mutfaklarında çalışan 377 personelin gıda güvenliği konusunu ne derece bildikleri ve uygulamalarında bu konularda ne kadar bilinçli davrandıklarını araştırmıştır. Araştırma 'ya göre, personelin bilgi düzeyleri bakımından olumlu sonuçlar elde edilmiştir. Otellerin yıldız sayıları ne olursa olsun HACCP sistemi uygulanmalı ve sonuçları resmî kurumlarca denetlenmesi gerektiği, ayrıca Oteller HACCP sistemini uygulamada personeli teşvik edici yöntemler geliştirmesi yönünde önerilerde bulunulmuştur

Can (2008), çalışmasında Balıkesir iline bağlı Erdek ilçesinde bulunan toplam 27 otel işletmesinin mutfak departmanlarında çalışan 113 personelin hijyen ve sanitasyon konusundaki bilgi ve uygulamalarını belirlemeye çalışmıştır. Araştırma sonucunda personelin, çoğunluğunun hijyen ve sanitasyon eğitimi almadıkları, işletmelerin çoğunluğunun da bu yönde eğitimi personeline vermedikleri tespit edilmiştir. Hijyen konusunda doğru bilgi sahibi olanların ise, bu bilgilerini kişisel yaşamlarından, eğitim süreçlerinden, kültürel ve sosyal yaşamlarından edindikleriyle kazandıkları düşünüldüğü sonucuna varılmıştır.

Şanlıer ve Tunç Hussein (2008), çalışmalarında Ankara'da bulunan otellerdeki 12 ayrı yiyecek içecek işletmesinde çalışan toplam 150 personelin hijyen durumlarını belirlemeyi 
amaçlamışlardır. Çalışma sonucunda hem mutfak şartlarının hem de personelin hijyenik kurallara uymasında aksaklıklar görülmüştür. Çalışan personelin $\% 49,3^{\prime}$ unun genel beslenme, $\% 37,3$ 'ünün yemek pişirme ve servis, \%72,0'sinin HACCP konusunda bilgisiz olması ve $\% 46,7^{\prime} \operatorname{sinin}$ hizmet içi eğitim almaması, gıda güvenliği ve sağlık konusunda yeterli bilginin olmaması, konuya ilişkin gerekli önemin personel ve işveren tarafından verilmemesinden kaynaklanıyor olabileceği kanaatine varılmıştır.

Ural (2007), çalışmasında Muğla iline bağlı Datça ilçesinde bulunan 27 konaklama işletmesinde çalışan toplam 224 personelin, kişisel hijyen bilgi ve uygulamalarının belirlenmesini amaçlamıştır. Değerlendirmeler sonucu, personelin çoğunluğunun kişisel hijyen ile ilgili uygulamayı gerçekleştiremedikleri görülmüştür.

Uyanık (2006), çalışmasında Afyonkarahisar'ın Sandıklı İlçesindeki Hüdai Kaplıcasında çalışan toplam 174 personele kişisel hijyen bilgisi ve tutumu ile ilgili anket uygulamıştır. Ayrıca hazırlanan değerlendirme formlarıyla kaplıcanın konaklama, sağlık, idare, havuz ve banyo birimleri kaplıca yönetmeliğine ve genel hijyen kurallarına göre değerlendirilmiştir. Araştırma sonuçlarına göre kaplıcanın konaklama, idare ve sağlik birimlerinde genel hijyen kurallarının büyük bir kısmına uyulduğu ancak havuz biriminde bu hijyen kurallarına tam anlamıyla uyulmadığı saptanmıştır.

Baş ve Sağlam (1997), çalışmalarında Ankara' da iki büyük otel ve toplam 84 personel üzerinde araştırma gerçekleştirmişlerdir. Araştırma sonuçlarına göre beslenme servisi personelinin kişisel ve çevre temizliği konusundaki bilgilerinin yeterli sayılabilecek düzeyde olduğunu, fakat yapılan gözlemlerde kişilerin bu bilgileri uygulamada kullanmadıkları sonucuna varılmıştır. Personel beslenme bilgisinin ise son derece yetersiz olduğu görülmüştür.

Güner (2017), çalışmasında Ankara ilinde bulunan ve toplu beslenme hizmeti veren 14 kurum mutfağında çalışan 107 mutfak personelin hijyen ve sanitasyon davranışlarının belirlenmesi, hijyen açısından mutfağın genel fiziki koşullarının değerlendirilmesi için anket uygulamıştır. Araştırmanın sonucunda; mutfakların hijyen açısından fiziki koşulları incelendiğinde büyük çoğunlukla uygun fiziki koşullara sahip olduğu ve personelin buna uygun davrandiğı görülmüştür.

Üzücü (2015), çalışmasında Kayseri kurum mutfağında ve yiyecek/içecek servisinde çalışan, 150 personelin hijyen yönünden yeterliliğinin incelenmesi ve durumlarının değerlendirilmesini amaçlamıştır. Veriler hazırlanan anket formuyla toplanmış, her çalışanın eğitim durumları belirlenip, hijyen kurallarına ilişkin davranışları tespit edilmiştir. Çalışmaya katılanların tamamının işe girdikten sonra düzenli sağlık kontrolünden geçtiği, çoğunun çalıştıkları kurumda veya daha önce hijyen eğitimi aldıkları sonucuna varılmıştır.

Kayalı (2013), çalışmasında Ankara kurum mutfağında ve yiyecek/içecek servisinde çalışan 58 personelin hijyen yönünden yeterliliğinin incelenmesi ve beslenme durumlarının değerlendirilmesi amacı ile anket uygulamıştır. Araştırmanın sonucuna göre toplu beslenme sistemlerinde çalışanların beslenme, sağlık, hijyen ve iş güvenliği alanlarında sürekli eğitimlerinin yapılması ve geliştirilecek kontrol mekanizmaları ile belirli periyotlarla izlenmesi gerektiğine ulaşılmıştır.

Turan (2009), çalışmasında Ankara ilinde bulunan 4 kamu kurum ve kuruluşunun yemekhanelerinde çalışan 300 mutfak personelinin el hijyeni bilgisi ve uygulamalarının incelenmesi için anket formu kullanılmıştır. Araştırma kapsamına alınan tüm personelin işe alınmadan önce sağlık kontrolünden geçtiği, daha önce sadece el hijyeni konusunda eğitim aldıkları belirlenmiştir. Anket formunda belirtilen görevlerden sonra ellerin yıkanıp 
yıkanmaması ile yaş ve çalışma süresi arasındaki farklılıklar önemsiz bulunmuştur. Personellerden 95 kişinin çok iyi bilgi düzeyine sahip, 55 kişinin yeterli, 148 kişinin orta ve sadece 2 kişinin yetersiz bilgi düzeyine sahip olduğu belirlenmiştir.

Sargın (2005), çalışmasında Ankara'da bulunan turizm sektörü açısından büyük öneme sahip 4 ve 5 yıldızlı toplam 6 otelin mutfak, restoran ve diğer servis alanlarında çalışan yiyecek ve içecek personelinin hijyen bilgileri ve uygulamalarının incelenmesini yapmıştır. Otel mutfakların hijyenik durumu " Hijyen Değerlendirme Formu" yardımıyla değerlendirilirken, hijyen standartlarındaki mevcut eksikliklerin ve uygulamadaki hataların düzeltilmesi için en üst kademedeki personelden başlamak üzere tüm personelin hizmet içi ve hizmet dişı eğitime ihtiyaçtan oldukları görülmektedir.

Annor ve Baiden (2011), çalışmalarında Gana otelcilik sektöründe çalışan personelin gıda hijyeni bilgilerini, tutumlarını, uygulamalarını belgelemek ve ayrıca gıdaların mikrobiyolojik durumunu ortaya koymayı amaçlamışlardır. Bu amaçla Gana da faaliyet gösteren 6 otel işletmesinde ki toplam 42 çalışanla yüz yüze anket yapılmıştır. Analiz sonuçlarına göre katılımcıların çoğunun gida hijyeni bilgisi olmasına rağmen, bunu uygulama da sergilemedikleri görülmüştür.

Huang vd. (2011), çalışmalarında Tayvan kültürünün eşsiz bir parçası olan ve yerel lezzetleri tatmak için ziyaret edilen turistik gece pazarlarındaki gıda hijyeni uygulamalarının mevcut durumunu ortaya koymayı amaçlamışlardır. Tayvan şehrinin en önemli 5 gece pazarında toplam 120 stant görevlisine anket formu uygulanmıştır. Analiz sonuçlarına göre sokak satıcıların hijyen uygulamalarının yetersiz olduğu ortaya konulmuştur.

Cavalli vd. (2016), çalışmalarında Brezilya'nın büyük bir kentinde şehir merkezinde satılan sokak yiyeceklerinin uluslararası gıda güvenliği standartlarına uygunluğunu değerlendirmek ve hijyen uygulamalarının hangi düzeyde olduğunu saptanmayı amaçlamışlardır. Araştırma da 43 satıcı ile derinlemesine mülakat yapılmıştır. Araştırma sonuçlarına göre satıcıların \%95'i yemek ve para işlemleri ile tuvalet molaları arasında ellerini yıkamadığı, \%33'ünün ise gıda güvenliği ve hijyen ile ilgili herhangi bir eğitim almadıkları tespit edilmiştir.

Odo ve Onoh (2018), çalışmalarında Nijerya Üniversitesi, Nsukka Kampüsü'ndeki gıda işleyicileri arasında gıda hijyeni bilgisi ve uygulamalarını belirlemeyi amaçlamışlardır. Araştırma kapsamında 165 gida işleyicisine anket formu uygulanmıştır. Araştırma sonuçlarına göre tüm katılımcıların gıda hijyeni konusunda bilgili olduğunu ve bunu uygulamada gösterdikleri görülmüştür.

Angelillo vd. (2001), çalışmalarında İtalya Calabria'daki hastanelerin gıda hijyeni yöntemleri ile mutfak personelinin bilgi, tutum ve uygulamalarını değerlendirmeyi amaçlamışlardır. Araştırma kapsaminda toplam 36 hastaneden, 27 tıbbi direktör ve 290 mutfak personeline anket uygulanmıştır. Araştırma sonuçlarına göre; hastanelerin yalnızca \%54'ü HACCP sistemini kullandığı, mutfak personelinin de yeterli bilgi ve uygulamaya sahip oldukları tespit edilmiştir.

Yapılan literatür çalışması ile mutfak departmanlarında çalışan personelin çoğunluğunun gıda güvenliği ve hijyen konusunda yeterli bilgiye sahip oldukları, fakat bilgiyi uygulama konusunda ciddi eksikliklerin olduğu tespit edilmiştir. Özellikle yurt dişında yapılan çalışma sonuçlarına göre bilgi ile uygulama arasında uyumluluk görülürken, yurt içinde ki yapılan çalışma sonuçlarında ise bu uyumun daha az olduğu söylenebilir. Yurt dışında ki yapılan çalışmalarda mutfak personelinin hijyen bilincinin dışında gıda güvenliği konusunda da duyarlı oldukları tespit edilirken, yurt içinde ki çalışmalarda ki gıda güvenliği hususu kısır kalmıştır. 


\section{ARAŞTIRMANIN YÖNTEMI Araştırmanın Amacı ve Önemi}

Bu araştırma, Şanlıurfa İl Merkezinde faaliyet gösteren konaklama işletmelerinin, restoran / bar ve mutfak departmanlarında çalışan personelin hijyen bilgisi ve uygulamalarını tespit etmek amacıyla yapılmıştır.

\section{Araştırma Problemi}

Bu araştırmada, konaklama işletmelerinde çalışan personelin kişisel hijyen bilgi düzeyleri ve uygulamalarının hangi aşamada olduğu, demografik özelliklerin kişisel hijyen bilgilerini etkileyip etkilemediği, ayrıca personelin kişisel hijyen bilgi ve uygulamaları arasında fark olup olmadığı gibi sorulara cevap aranmıştır.

\section{Evren ve Örneklem}

Şanlıurfa İl Kültür ve Turizm Müdürlügü 2021 yılı verilerine göre Şanlıurfa il merkezinde 11 turizm işletme belgeli ve 21 belediye belgeli toplam 32 konaklama tesisi bulunmaktadır (https://sanliurfa.ktb.gov.tr). Araştırma evrenini 32 konaklama tesisinde bulunan toplam 380 restoran / bar ve mutfak departmanlarında çalışan personel olușturmaktadır. Araştırmanın örneklemini ise, 32 konaklama tesisinden tam sayım yöntemi ile ulaşılan 207 personel oluşturmaktadır.

\section{Veri Toplama Aracı ve İçeriği}

Şanlıurfa İl Merkezinde faaliyette olan konaklama işletmelerinin restoran / bar ve mutfak departmanlarında çalışan personelin hijyen bilgisi ve uygulamalarını tespit etmeye yönelik yapılan bu araştırmada ki veriler, Ural (2007)' in “Konaklama İşletmelerinde Çalışan Personelin Kişisel Hijyen Bilgileri ve Uygulamaları Üzerine Bir Araştırma" adlı çalışmasında geliştirmiş olduğu anket formu kullanılarak oluşturulmuştur. Anket formu üç bölümden oluşmaktadır. Birinci bölümde katılımcıların demografik özelliklerini belirlemeye yönelik 9 adet soru bulunmaktadır. İkinci ve üçüncü bölümde ise personelin kişisel hijyen bilgi ve uygulamalarına ilişkin toplam 31 soruyu içermektedir. Yılın 12 ayı faaliyette olan konaklama işletmelerinin bahar aylarında yüksek kapasitede çalıştıkları göz önüne alınarak anketler, işletme müdürlerinin izinleri alınarak departman müdür ve amirlerine gerekli açıklamalar yapıldıktan sonra 30 Mart07 Nisan 2021 tarihleri arasında anket formları personele uygulatılmak üzere teslim edilmiş ve 12-14 Nisan 2021 tarihleri arasında anket formları toplanmıştır.

\section{Verilerin Analizi}

Verilerin analizinde, personele ait demografik bilgiler ve kişisel hijyen uygulamaları sayı ve yüzdelerle verilmiş, farklılık analizleri için ise "Khi-Kare Testi $(\chi 2)$ ” yapılmıştır. Khi-Kare analizi ile demografik faktörler karşılaştırılarak gözlemlenen değerler ile beklenen değerler arasındaki uygunluk oranları elde edilmeye çalışılmıştır (Can, 2008: 71). 


\section{BULGULAR}

$\mathrm{Bu}$ başlık altında araştırmaya katılan personelin demografik bilgileri, kişisel hijyen bilgi uygulamaları ve kişisel hijyen konusundaki düşünceleri incelenmiştir.

\section{Konaklama İşletmelerine ve Personele İlişkin Demografik Bulgular}

Personelin; yaş, cinsiyet, medeni durum, gelir, eğitim durumu, görev yaptığı departman ile çalıştıkları konaklama işletmesinin türü ve yıldız sayısını gösteren tanımlayıcı bilgileri Tablo 1'de verilmiştir.

Tablo 1. Personelin Demografik Özelliklerine Göre Dağılımı

\begin{tabular}{|c|c|c|c|c|c|c|c|}
\hline \multicolumn{2}{|c|}{ Demografik Özellikler } & \multicolumn{2}{|c|}{$\begin{array}{c}\text { Erkek } \\
(\mathrm{n}=172)\end{array}$} & \multicolumn{2}{|c|}{$\begin{array}{l}\text { Kadın } \\
(\mathrm{n}=35)\end{array}$} & \multicolumn{2}{|c|}{$\begin{array}{l}\text { Toplam } \\
(\mathrm{n}=207)\end{array}$} \\
\hline & & Sayı & $\%$ & Sayı & $\%$ & Say1 & $\%$ \\
\hline \multirow{5}{*}{ Yaş } & $18-25$ & 65 & 37,8 & 11 & 31,4 & 76 & 36,7 \\
\hline & $26-33$ & 53 & 30,8 & 10 & 28,6 & 63 & 30,4 \\
\hline & $34-41$ & 45 & 26,2 & 7 & 20,0 & 52 & 25,1 \\
\hline & $42-49$ & 7 & 4,1 & 4 & 11,4 & 11 & 5,3 \\
\hline & 50 ve üzeri & 2 & 1,2 & 3 & 8,6 & 5 & 2,4 \\
\hline \multirow{2}{*}{ Medeni Durum } & Evli & 105 & 61,0 & 16 & 45,7 & 121 & 58,5 \\
\hline & Bekâr & 67 & 39,0 & 19 & 54,3 & 86 & 41,5 \\
\hline \multirow{4}{*}{ Ortalama Aylık Gelir } & 2000TL ve altı & 90 & 52,3 & 12 & 34,3 & 102 & 49,3 \\
\hline & 2001TL-4000TL & 72 & 41,9 & 21 & 60,0 & 93 & 44,9 \\
\hline & 4001TL-5000TL & 7 & 4,1 & 2 & 5,7 & 9 & 4,3 \\
\hline & 5001 TL ve üstü & 3 & 1,7 & 0 & 0,0 & 3 & 1,4 \\
\hline \multirow{6}{*}{ Eğitim Durumu } & Okur -Yazar Değil & 3 & 1,7 & 2 & 5,7 & 5 & 2,4 \\
\hline & İlkokul & 31 & 18,0 & 5 & 14,3 & 36 & 17,4 \\
\hline & Ortaokul & 53 & 30,8 & 6 & 17,1 & 59 & 28,5 \\
\hline & Lise & 60 & 34,9 & 8 & 22,9 & 68 & 32,9 \\
\hline & Üniversite & 22 & 12,8 & 14 & 40,0 & 36 & 17,4 \\
\hline & Y. Lisans / Doktora & 3 & 1,7 & 0 & 0,0 & 3 & 1,4 \\
\hline \multirow{5}{*}{ Mezun Olunan Bölüm } & Turizm & 20 & 11,6 & 13 & 37,1 & 33 & 15,9 \\
\hline & Temel eğitim (genel) & 66 & 38,4 & 9 & 25,7 & 75 & 36,2 \\
\hline & Diğer & 12 & 7,0 & 1 & 2,9 & 13 & 6,3 \\
\hline & $\begin{array}{l}\text { Cevap verilmemiş } \\
\text { (boş) }\end{array}$ & 71 & 41,3 & 11 & 31,4 & 82 & 39,6 \\
\hline & Meslek lisesi & 3 & 1,7 & 1 & 2,9 & 4 & 1,9 \\
\hline
\end{tabular}

Araştırma kapsamına alınan personelin, kişisel özelliklerine göre dağılımı incelendiğinde, erkek personelin \%37,8' inin, kadın personelin \%31,4'ünün 25 ve altındaki yaş aralığında, erkek personelin \%30,8' inin, kadın personelin \%28,6'sının 26- 33 yaş aralığında, erkek personelin $\% 26,2^{\prime}$ sinin, kadın personelin \%20,0'inin ise 34 ve üzeri yaş aralığında, erkek personelin $\% 4,1^{\prime}$ inin, kadın personelin \%11,4'inin ise $42-49$ yaş aralığında olduğu saptanmıştır. Konaklama 
işletmelerinde çalışan personelin genellikle genç bireylerden oluştuğu görülmektedir. Konaklama işletmelerinde çalışan personelin medeni durumlarına bakıldığında yarısından fazlasının (\%58,5) evli olduğu tespit edilmiştir. Personelin gelir durumları göz önüne alındığında, büyük çoğunluğunun $(\% 49,3)$ aylık gelirinin 2.000 TL ve altı olduğu görülmüştür. Personelin eğitim durumlarına göre dağılımlarına bakıldığında büyük bir çoğunluğunun $(\% 32,9)$ lise mezunu olduğu, saptanmıştır.

Tablo 2. Konaklama İşletmesinin Özellikleri ve Çalışılan Departmana Göre Dağılım

\begin{tabular}{|c|c|c|c|c|c|c|c|}
\hline \multirow{2}{*}{\multicolumn{2}{|c|}{ İşletmenin Özellikleri }} & \multicolumn{2}{|c|}{$\begin{array}{l}\text { Erkek } \\
\text { (n 172) }\end{array}$} & \multicolumn{2}{|c|}{$\begin{array}{l}\text { Kadın } \\
\text { (n 35) }\end{array}$} & \multicolumn{2}{|c|}{$\begin{array}{l}\text { Toplam } \\
\text { (n 207) }\end{array}$} \\
\hline & & Sayı & $\%$ & Sayı & $\%$ & Sayı & $\%$ \\
\hline \multirow{4}{*}{ Türü } & Otel & 137 & 79,7 & 30 & 85,7 & 167 & 80,7 \\
\hline & Pansiyon & 1 & 0,6 & 1 & 2,9 & 2 & 1,0 \\
\hline & Apart Otel & 0 & 0,0 & 1 & 2,9 & 1 & 0,5 \\
\hline & Butik Otel & 34 & 19,8 & 3 & 8,6 & 37 & 17,9 \\
\hline \multirow{7}{*}{ Yild1z } & 1 Yildiz & 2 & 1,2 & 5 & 14,3 & 7 & 3,4 \\
\hline & 2 Yildiz & 4 & 2,3 & 1 & 2,9 & 5 & 2,4 \\
\hline & 3 Yıldiz & 24 & 14,0 & 5 & 14,3 & 29 & 14,0 \\
\hline & 4 Yıldiz & 23 & 13,4 & 5 & 14,3 & 28 & 13,5 \\
\hline & 5 Yıldız & 74 & 43,0 & 11 & 31,4 & 85 & 41,1 \\
\hline & Belediye belgeli & 44 & 25,6 & 8 & 22,9 & 52 & 25,1 \\
\hline & Cevap yok & 1 & 100,0 & 0 & 0,0 & 1 & 0,48 \\
\hline \multirow{2}{*}{ Departman } & Restoran/bar & 103 & 59,9 & 16 & 45,7 & 119 & 57,5 \\
\hline & Mutfak & 69 & 40,1 & 19 & 54,3 & 88 & 42,5 \\
\hline
\end{tabular}

İşletme türleri göz önüne alındığında, personelin yarıdan fazlasının $(\% 80,7)$ otellerde çalıştığı ve bunu sırasiyla butik otel $(\% 17,9)$, pansiyon $(\% 1)$ ve apart otelin $(\% 0,5)$ takip ettiği görülmektedir. Otellerde çalışan erkek personel oranı $\% 82$, kadın personel oranı ise \%18' dir. Bütün işletme türlerine göre erkeklerin oranı kadınlara göre oldukça fazladır. Personelin çalıştığı konaklama işletmelerinin yıldız sayısına bakıldığında, \%41,1' inin beş yıldızlı otellerde, $\% 25,1^{\prime}$ inin yıldızı olmayan Belediye Belgeli otellerde, \%13,5' inin dört yıldızlı, \%14' ünün üç yıldızlı ve \%5,8'inin bir ve iki yıldızlı işletmelerde çalıştı̆̆ saptanmıştır. Personelin konaklama işletmelerinde çalıştıkları departmanlara göre dağılımı incelendiğinde ise, büyük çoğunluğunun $(\% 57,5)$ restoran-barda, geri kalanın ise $(\% 42,5)$ mutfak bölümünde çalıştığı görülmüştür.

\section{Personelin Kişisel Hijyen Konusundaki Düşüncelerine İlişkin Bulgular}

Personelin kişisel hijyen konusundaki fikirlerine ve personelin çalıştığ kişisel hijyene önem verme durumuna ait bulgular Tablo 3'de yer almaktadır. Tablo 'ya göre personelin \%46,4' ünün kişisel hijyeni uygulama nedeninin kirlendiğini hissetmesinden kaynaklandığı, \%44,1'inin alışkanlıklarından \%8,2'sinin ise çevrenin uyarılarından dolayı kişisel hijyen uygulamalarını yapmaktadır.

Personelin kişisel hijyeni uygulama durumuna bakıldığında \%71,5'inin kişisel hijyen ile ilgili bilgilerini kendi yaşantılarında uyguladığı, \%28,5'inin ise kişisel hijyen kurallarını 
uygulamadığını belirtmiştir. Uygulamayanların çoğunluğunun ise \%37,29 hijyen kurallarını bildiğini ama uygulamayı ihmal ettiklerini, \%25,42'sinin ise zaman bulamadıkları, kalan $\% 37,29$ 'luk kısmının ise bilgilerin gereksiz olduğu vb. sebeplerden dolayı uygulamadıkları saptanmıştır. Personelin, kişisel hijyen ile ilgili eğitim alma durumları göz önüne alındığında, yarısından fazlasının $(\% 51,7)$ kişisel hijyen uygulamaları konusunda eğitim almadığı, eğitim alan personelin ise aldığı eğitimi alışkanlığa dönüştürerek kendi yaşantısında uyguladığ görülmektedir. Eğitim alanların oranlarının yüksek olması bu konuda yeterli bilgiye sahip olduklarını göstermektedir.

Tablo 3. Hijyen Cevaplarına İlişkin Dağılım

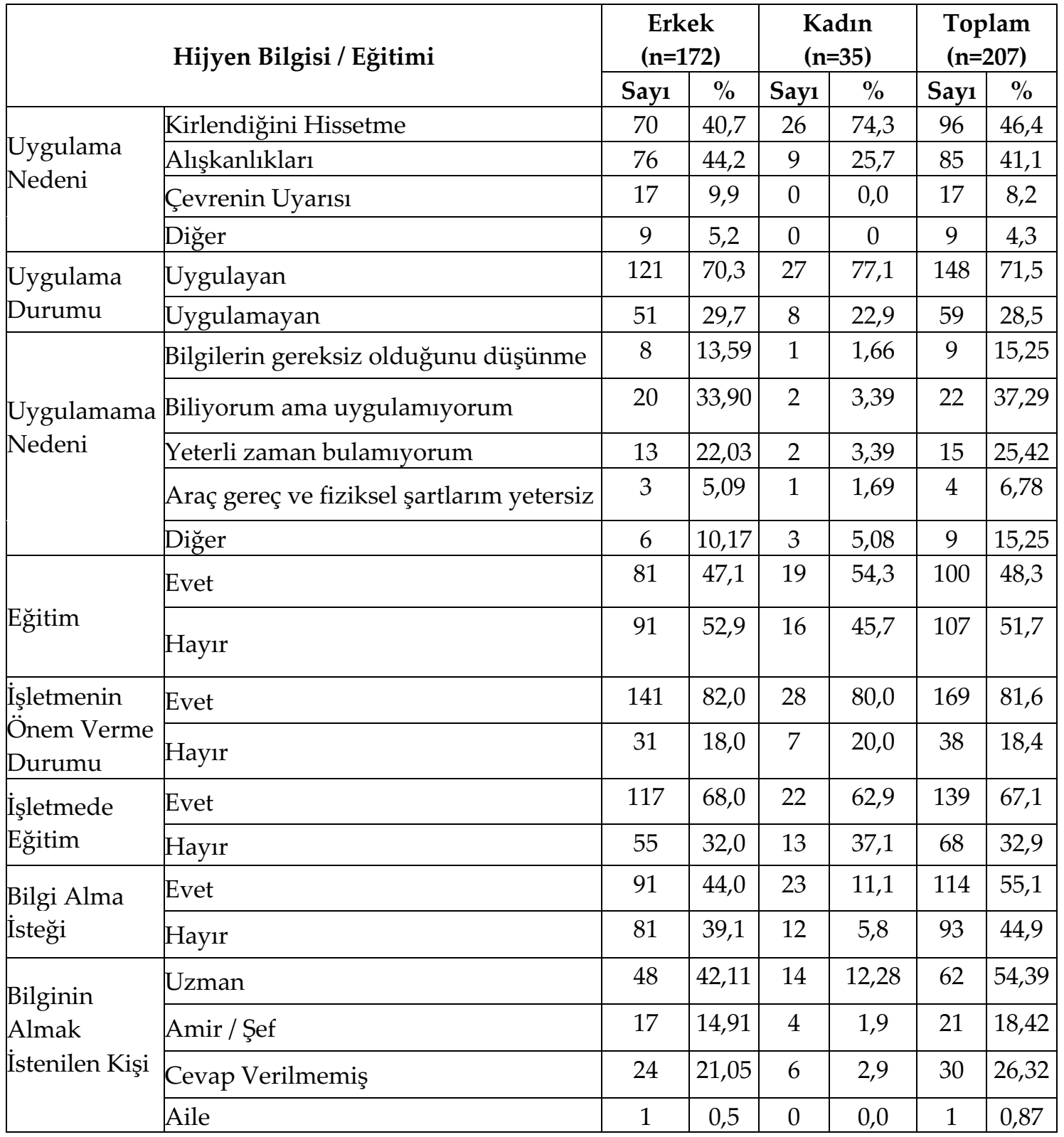




\section{Personelin Kişisel Hijyen Bilgi ve Uygulamalarına İlişkin Bulgular}

Personelin kişisel hijyen ile ilgili bilgi ve uygulamalarına ilişkin bulgular Tablo 4'te yer almaktadır.

Tablo 4. Personel Kişisel Hijyen Uygulamaları

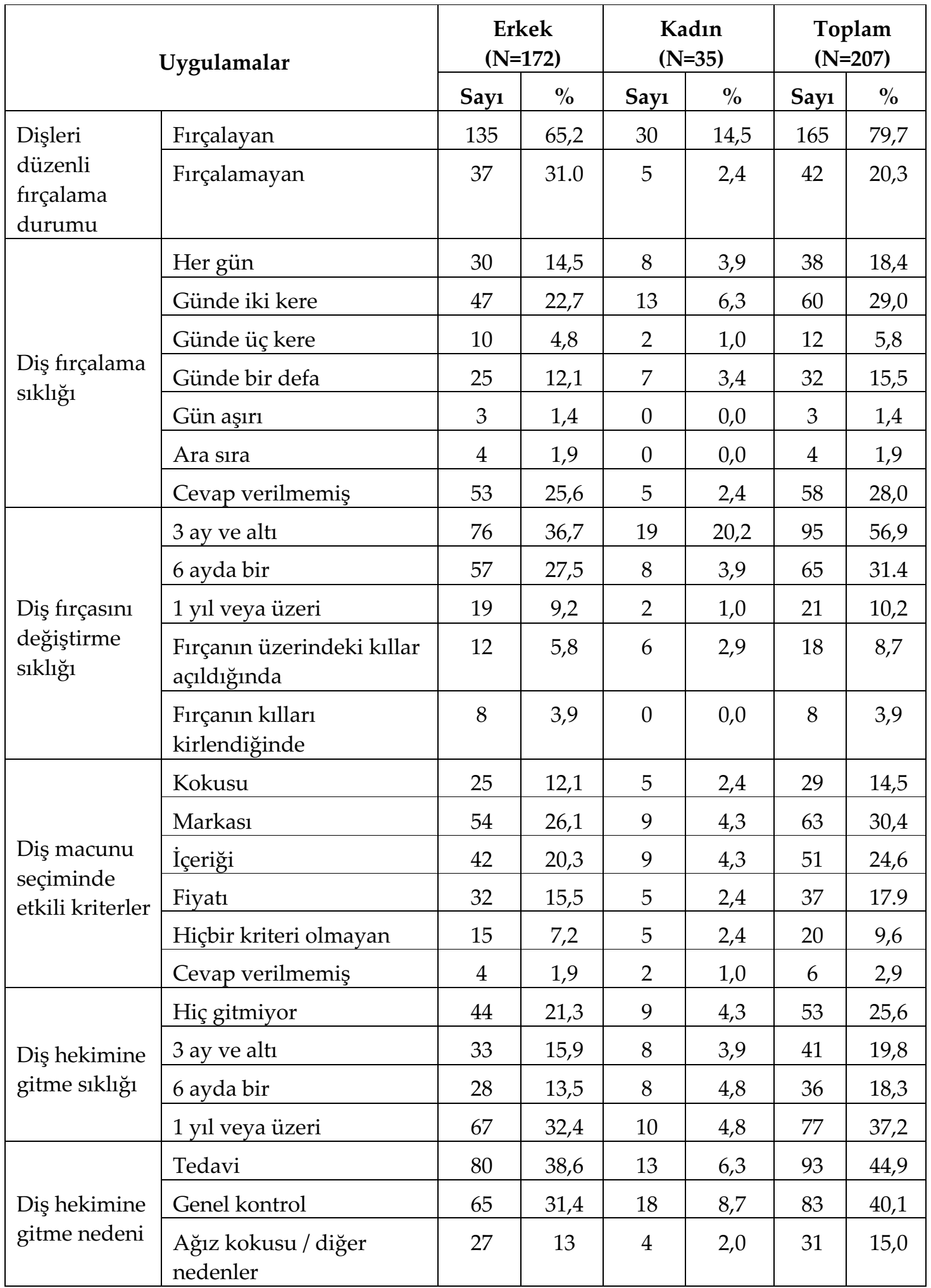


Tablo 5. Personelin El Yıkama Durumlarına Göre Dağılımı

\begin{tabular}{|c|c|c|c|c|c|c|c|c|c|}
\hline \multirow{2}{*}{ El Yıkama Durumları } & & \multicolumn{2}{|c|}{$\begin{array}{l}\text { Erkek } \\
(\mathrm{N}=172)\end{array}$} & \multicolumn{2}{|c|}{$\begin{array}{l}\text { Kadın } \\
(\mathrm{N}=35)\end{array}$} & \multicolumn{2}{|c|}{$\begin{array}{l}\text { Toplam } \\
(\mathrm{N}=207)\end{array}$} & \multirow{2}{*}{$\mathbf{X}^{2}$} & \multirow{2}{*}{$\mathbf{P}$} \\
\hline & & Sayı & $\%$ & Sayı & $\%$ & Sayı & $\%$ & & \\
\hline \multirow{2}{*}{ Yemeklerden önce } & Evet & 145 & 84,3 & 23 & 65,7 & 168 & 81,2 & \multirow[t]{2}{*}{,392 } & \multirow[t]{2}{*}{, $013^{*}$} \\
\hline & Hayır & 27 & 15,7 & 12 & 34,3 & 39 & 18,8 & & \\
\hline \multirow{2}{*}{ Yemeklerden sonra } & Evet & 120 & 69,8 & 25 & 71,4 & 145 & 70,0 & \multirow[t]{2}{*}{,459 } & \multirow[t]{2}{*}{, 510} \\
\hline & Hayır & 52 & 30,2 & 10 & 28,6 & 62 & 30 & & \\
\hline \multirow{2}{*}{ Sabah kalkınca yıkarım } & Evet & 94 & 54,7 & 13 & 37,1 & 107 & 51,7 & \multirow[t]{2}{*}{, 501} & \multirow[t]{2}{*}{, $044^{\prime}$} \\
\hline & Hayır & 78 & 45,3 & 22 & 62,9 & 100 & 48,3 & & \\
\hline \multirow{2}{*}{ Tokalaşınca yıkarım } & Evet & 41 & 23,8 & 3 & 8,6 & 44 & 21,3 & \multirow[t]{2}{*}{410} & \multirow[t]{2}{*}{, $030^{\circ}$} \\
\hline & Hayır & 131 & 76,2 & 32 & 91,4 & 163 & 78,7 & & \\
\hline \multirow{2}{*}{ Tuvaletten önce } & Evet & 49 & 28,5 & 6 & 17,1 & 55 & 26,6 & \multirow[t]{2}{*}{,443 } & \multirow[t]{2}{*}{ 118 } \\
\hline & Hayır & 123 & 71,5 & 29 & 82,9 & 152 & 73,4 & & \\
\hline \multirow{2}{*}{ Tuvaletten sonra } & Evet & 140 & 81,4 & 29 & 82,9 & 169 & 81,6 & \multirow[t]{2}{*}{,388 } & \multirow[t]{2}{*}{, 528} \\
\hline & Hayır & 32 & 18,6 & 6 & 17,1 & 38 & 18,4 & & \\
\hline \multirow{2}{*}{ Dışarıdan eve gelince } & Evet & 74 & 43,0 & 14 & 40,0 & 88 & 42,5 & \multirow[t]{2}{*}{,496 } & \multirow[t]{2}{*}{,446 } \\
\hline & Hayır & 98 & 57,0 & 21 & 60,0 & 119 & 57,5 & & \\
\hline Hancurdukton cronr & Evet & 78 & 45,3 & 6 & 17,1 & 84 & 40,6 & ,492 &, $001^{*}$ \\
\hline 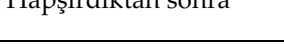 & Hayır & 94 & 54,7 & 29 & 82,9 & 123 & 59,4 & & \\
\hline Cipon iatilon conm & Evet & 32 & 18,6 & 1 & 2,9 & 33 & 15,9 & 367 &, $011^{*}$ \\
\hline Sigara içtikten sonra & Hayır & 140 & 81,4 & 34 & 97,1 & 174 & 84,1 & & \\
\hline Öl_ïrd̈̈lttnn & Evet & 57 & 33,1 & 8 & 22,9 & 65 & 31,4 & 465 & ,160 \\
\hline UKsuraukten sonra & Hayır & 115 & 66,9 & 27 & 77,1 & 142 & 68,6 & & \\
\hline Burun ve ağız gibi & Evet & 91 & 52,9 & 11 & 31,4 & 102 & 49,3 &, 501 &, $016^{*}$ \\
\hline $\begin{array}{l}\text { bölgelere dokunduktan } \\
\text { sonra }\end{array}$ & Hayır & 81 & 47,1 & 24 & 68,6 & 105 & 50,7 & & \\
\hline Sünhelenilen her & Evet & 115 & 66,9 & 27 & 77,1 & 142 & 68,6 & ,465 & 160 \\
\hline durumda & Hayır & 57 & 33,1 & 8 & 22,9 & 65 & 31,4 & & \\
\hline Çiğ gıdalara (özellikle & Evet & 73 & 42,4 & 12 & 34,3 & 85 & 41,1 & 493 & ,242 \\
\hline et) dokunduktan sonra & Hayır & 99 & 57,6 & 23 & 65,7 & 122 & 58,9 & & \\
\hline Paraya dokunduktan & Evet & 60 & 34,9 & 8 & 22,9 & 68 & 32,9 & 471 & 117 \\
\hline sonra & Hayır & 112 & 65,1 & 27 & 77,1 & 139 & 67,1 & & \\
\hline Temiz olmayan yerlere & Evet & 109 & 63,4 & 22 & 62,9 & 131 & 63,3 & 483 &, 549 \\
\hline temastan sonra & Hayır & 63 & 36,6 & 13 & 37,1 & 76 & 36,7 & & \\
\hline Mendil kullandıktan & Evet & 32 & 18,6 & 2 & 5,7 & 34 & 16,4 & ,371 &, $043^{*}$ \\
\hline sonra & Hayır & 140 & 81,4 & 33 & 94,3 & 173 & 83,6 & & \\
\hline
\end{tabular}

Personelin dişlerini fırçalama durumlarına bakıldığında, çoğunluğu $(\% 79,7)$ dişlerini düzenli olarak fırçaladığını düşünmekte ve personelin sadece $\% 34,8$ ' i dişlerini günde iki veya daha fazla fırçaladığı tablodan ulaşılmaktadır. Araştırmaya katılan personelin diş fırçası kullanım süresi ve diş macunu seçimi incelendiğinde; \%56,9' unun 3 ay ve altı, \%31,4' ü 6 ayda bir, \%10,2'si 1 yıl veya üzeri ve $\% 8,7^{\prime}$ si fırçanın kılları açıldığında diş fırçasını değiştirdiğini, diş macunu seçiminde ise personelin \%24,6' sı macunun içeriğini, \%17,9 'luk kısmı ise macunun fiyatının belirleyici kriter olduğunu belirtmişlerdir. Personelin diş hekimine gitme sıklığına göre dağılımı 
incelendiğinde, çoğunluğunun (\%37,2) 1 yıl veya üzeri, \%18,3’ ünün 6 ayda bir, \%19,8' inin 3 ay ve altı ve $\% 25,6^{\prime}$ sının ise hiç gitmediği saptanmıştır. Personelin diş hekimine gitme nedenlerine bakıldığında, büyük çoğunluğunun $(\% 59,9)$ ağız kokusundan kaynaklı diş hekimine gittikleri görülmüştür. Tablo 5'te personelin el yıkama durumlarına göre dağılımları verilmektedir.

Tablo 5 incelendiğinde, personelin \%63,3' ünün temiz olmayan çalışma alanları ve malzemelerle temastan sonra, \%49,3' ünün kulak, burun ve ağız gibi bölgelere dokunduktan sonra, $\% 41,1^{\prime}$ inin çiğ gıdalara özellikle ete dokunduktan sonra, \%15,9' unun sigara içtikten sonra, \%70' inin yemeklerden sonra, $\% 75,4^{\prime}$ ünün paraya dokunduktan sonra ve dışarıdan eve gelince, $\% 68,6^{\prime}$ sının ellerin kirlendiğinden şüphelenilen her durumda, \%81,6' sının ise tuvaletten sonra ellerini yıkadıkları saptanmıştır. Personelin el yıkama durumları ile cinsiyetleri arasında ilişkiye bakıldığında; yemeklerden önce, sabah kalkınca, tokalaşınca, hapşırdıktan sonra, mendil kullandıktan sonra, burun ve ağız gibi bölgelere dokunduktan sonra ve sigara içtikten sonra ellerini yıkadığını belirten kadın ve erkek personel arasında istatistiksel olarak anlamlı bir farkın olduğu saptanmiştır $(\mathrm{P}<0.05)$. Tablo 6 'da personelin işyerinde sabun ve havlu bulundurma durumunun dağılımı yer almaktadır.

Tablo 6. İşyerinde Sabun ve Havlu Bulundurma Durumuna Göre Dağılımı

\begin{tabular}{|c|c|c|c|c|c|c|c|}
\hline & \multicolumn{2}{|c|}{$\begin{array}{c}\text { Erkek } \\
(n=172)\end{array}$} & \multicolumn{2}{|c|}{$\begin{array}{l}\text { Kadın } \\
(\mathrm{n}=35)\end{array}$} & \multicolumn{2}{|c|}{$\begin{array}{l}\text { Toplam } \\
(\mathrm{n}=207)\end{array}$} \\
\hline & & Sayı & $\%$ & Say1 & $\%$ & Sayı & $\%$ \\
\hline \multirow{2}{*}{$\begin{array}{l}\text { El sabunu } \\
\text { türü }\end{array}$} & Sivi sabun & 120 & 69,8 & 29 & 82,9 & 149 & 72,0 \\
\hline & Katı sabun & 52 & 30,2 & 6 & 17,1 & 58 & 28.0 \\
\hline \multirow[t]{3}{*}{$\begin{array}{l}\text { El kurulama } \\
\text { Şekli }\end{array}$} & $\begin{array}{l}\text { Kâğıt } \\
\text { Havlu }\end{array}$ & 146 & 84,9 & 31 & 88,6 & 177 & 85,5 \\
\hline & $\begin{array}{l}\text { Ortak } \\
\text { Havlu }\end{array}$ & 15 & 8,7 & 4 & 11,4 & 19 & 9,2 \\
\hline & Diğer & 11 & 6,4 & 0 & 0,0 & 11 & 5,3 \\
\hline
\end{tabular}

Araştırmaya alınan personelin \%72' sinin sıvı sabun kullanmayı tercih ettiği, \%85,5'inin kâğıt havlu kullandığı saptanmıştır. Tablo 7'de personelin kişisel eşyalarını bireysel veya diğer bireylerle ortak kullanma durumuna göre dağılımına yer verilmiştir.

Tablo 7'de personelin, kişisel eşyalarını bireysel ve ortak kullanımına göre dağılımı incelendiğinde, personelin \%99' unun iç çamaşırlarını, \%99,6'sının diş fırçasını, \%95,2'sinin çoraplarını, \%97,1'inin ayakkabısını, \%86,5'inin banyo havlusunu, \%94,2'sinin gömlek ve tişörtünü bireysel olarak kullandığı, \%61,4'ünün el havlusunu, \%34,3'ünün yüz havlusunu, $\% 22,2$ 'sinin ayak havlusunu ortak kullandığı saptanmıştır. Personelin kişisel eşyalarını bireysel ya da ortak kullanma durumları ile cinsiyetleri arasındaki ilişkiye bakıldığında, el havlusu bireysel ve ortak kullanımı ile erkek ve kadın oranları arasında istatistiksel olarak anlamlı bir farkın olduğu saptanmıştır $\left(\mathrm{X}^{2}=0,488 ; \mathrm{P}<0.05\right)$. Tablo 8 ve sonraki tablolarda personelin kişisel hijyen ile ilgili bilgi sorularına verdikleri doğru ve yanlış cevaplara göre dağılımı verilmektedir. 
Tablo 7. Personelin Kişisel Eşyaların Kullanma Durumuna Göre Dağılımı

\begin{tabular}{|c|c|c|c|c|c|c|c|c|c|}
\hline \multicolumn{2}{|c|}{ Kişisel Eş. } & \multicolumn{2}{|c|}{$\begin{array}{c}\text { Erkek } \\
(n=172)\end{array}$} & \multicolumn{2}{|c|}{$\begin{array}{l}\text { Kadın } \\
(\mathrm{n}=35)\end{array}$} & \multicolumn{2}{|c|}{$\begin{array}{l}\text { Toplam } \\
(\mathrm{n}=207)\end{array}$} & $X^{2}$ & $\mathbf{P}$ \\
\hline \multirow{2}{*}{ İç çamaşırı } & Bireysel & $\begin{array}{c}\text { Sayı } \\
170\end{array}$ & $\begin{array}{r}\% \\
98,8\end{array}$ & $\begin{array}{c}\text { Sayı } \\
35\end{array}$ & $\begin{array}{c}\mathbf{\%} \\
100.0\end{array}$ & $\begin{array}{l}\text { Sayı } \\
205\end{array}$ & $\begin{array}{r}\% \\
99,0\end{array}$ & \multirow{2}{*}{,098 } & \multirow[b]{2}{*}{690} \\
\hline & Ortak & 2 & 1,2 & 0 & 0,0 & 2 & 1,0 & & \\
\hline \multirow[t]{2}{*}{ Gömlek/ Tişört } & Bireysel & 166 & 96,5 & 29 & 82,9 & 195 & 94.2 & \multirow{2}{*}{,234 } & \multirow{2}{*}{, $007^{*}$} \\
\hline & Ortak & 6 & 3,5 & 6 & 17,1 & 12 & 5,8 & & \\
\hline \multirow[t]{2}{*}{ Pantolon/şort } & Bireysel & 165 & 95,9 & 29 & 82,9 & 194 & 93,7 & \multirow{2}{*}{ 243 } & \multirow{2}{*}{, $011^{*}$} \\
\hline & Ortak & 7 & 4,1 & 6 & 17,1 & 13 & 6,3 & & \\
\hline \multirow{2}{*}{ Çorap } & Bireysel & 168 & 97,7 & 29 & 82,9 & 197 & 95,2 & \multirow{2}{*}{,215 } & \multirow{2}{*}{, $002^{*}$} \\
\hline & Ortak & 4 & 2,3 & 6 & 17,1 & 10 & 4,8 & & \\
\hline \multirow{2}{*}{ Tarak } & Bireysel & 144 & 83,7 & 23 & 65,7 & 167 & 80,7 & \multirow{2}{*}{,396 } & \multirow{2}{*}{, $016^{*}$} \\
\hline & Ortak & 28 & 16,3 & 12 & 34,3 & 40 & 19,3 & & \\
\hline \multirow{2}{*}{ Diş fırçası } & Bireysel & 168 & 97,7 & 34 & 97,1 & 202 & 99.6 & \multirow{2}{*}{,154 } & \multirow{2}{*}{603} \\
\hline & Ortak & 4 & 2,3 & 1 & 2,9 & 5 & 2,4 & & \\
\hline \multirow{2}{*}{ Banyo lifi } & Bireysel & 137 & 79,7 & 24 & 68,6 & 161 & 77,8 & & \\
\hline & Ortak & 35 & 20,3 & 11 & 31,4 & 46 & 22,2 & ,417 &, 114 \\
\hline & Bireysel & 149 & 86,6 & 30 & 85,7 & 179 & 86,5 & & \\
\hline Danyo naviusu & Ortak & 23 & 13,4 & 5 & 14,3 & 28 & 13,5 & (343 & (503, \\
\hline & Bireysel & 114 & 66,3 & 13 & 37,1 & 127 & 61,4 & & \\
\hline Ei maviusu & Ortak & 58 & 33,7 & 22 & 62,9 & 127 & 61,4 & , 400 & , \\
\hline & Bireysel & 115 & 66,9 & 21 & 60,0 & 136 & 65,7 & & \\
\hline ruz naviusu & Ortak & 57 & 33,1 & 14 & 40,0 & 71 & 34,3 & , $4 / 0$ & ו \\
\hline & Bireysel & 135 & 78,55 & 26 & 74,3 & 161 & 77,8 & & \\
\hline Rуак Tiaviusu & Ortak & 37 & 21,5 & 9 & 25,7 & 46 & 22.2 &, 417 & , 365 \\
\hline & Bireysel & 167 & 97,1 & 34 & 97,1 & 201 & 97,1 & & \\
\hline AуаккаDI & Ortak & 5 & 2,9 & 1 & 2,9 & 6 & 2,9 & 168 & , 132 \\
\hline & Bireysel & 139 & 80,8 & 25 & 71,4 & 164 & 79,2 & & \\
\hline Iermk & Ortak & 33 & 19,2 & 10 & 28,6 & 43 & 20,8 & , 407 &, 104 \\
\hline
\end{tabular}

${ }^{*} \mathrm{P}<0.05$ 
Tablo 8. Kişisel Hijyen ile İlgili Sorulara Ait Seçenekler ve Verilen Cevaplara Ait Dağglım

\begin{tabular}{|c|c|c|c|c|c|c|c|}
\hline \multirow[t]{2}{*}{ Sorular } & \multirow[t]{2}{*}{ Seçenekler } & \multicolumn{2}{|c|}{ Erkek } & \multicolumn{2}{|c|}{ Kadın } & \multicolumn{2}{|c|}{ Toplam } \\
\hline & & Say1 & $\%$ & Sayı & $\%$ & Sayı & $\%$ \\
\hline \multirow{4}{*}{$\begin{array}{l}\text { Vücut } \\
\text { banyosuyla } \\
\text { ilgili doğru } \\
\text { ifade } \\
\text { hangisidir? }\end{array}$} & Vücudun iki haftada bir sabunlanarak durulanması gerekir & 15 & 7,2 & 6 & 2,9 & 21 & 10,1 \\
\hline & Vücudun her gün sabunlanarak durulanması gerekir/Doğru & 101 & 48,8 & 21 & 10,1 & 122 & $\mathbf{5 8 , 9}$ \\
\hline & Vücudun haftada bir sabunlanarak durulanması gerekir & 19 & 9,2 & 1 & 0,5 & 20 & 9,7 \\
\hline & Vücut sabunlanmadan, her gün sabah akşam duş yapılması gerekir & 37 & 17,9 & 7 & 3,4 & 44 & 21,3 \\
\hline \multirow{3}{*}{$\begin{array}{c}\text { Hangisi } \\
\text { vücut } \\
\text { banyosunu } \\
\mathrm{n} \\
\text { etkilerinde } \\
\mathrm{n} \text { değildir? }\end{array}$} & Vücut kokularının uzaklaşmasını sağlar & 12 & 5,8 & 5 & 2,4 & 17 & 8,2 \\
\hline & Deriden ter, yağ ve bazı mikroorganizmaların uzaklaşmasını sağlar & 26 & 12,6 & 6 & 2,9 & 32 & 15,5 \\
\hline & Vücuttaki fazla yağların erimesini sağlar/Doğru & 100 & 48,3 & 22 & 10,6 & 122 & $\mathbf{5 8 , 9}$ \\
\hline \multirow{4}{*}{$\begin{array}{l}\text { Saç } \\
\text { temizliği } \\
\text { ile ilgili } \\
\text { yanlış } \\
\text { uygulama } \\
\text { hangisidir? }\end{array}$} & Kirli ve ölü kıllar için saçlar düzenli olarak fırçalanmalıdır & 34 & 16,4 & 6 & 2,9 & 40 & 19,3 \\
\hline & Yağlı saçlar daha sık yıkanmalıdır & 20 & 9,7 & 4 & 1,9 & 24 & 11,6 \\
\hline & $\begin{array}{l}\text { Saçlar kurutulurken hızlı ve kuvvetli bir şekilde fırçalanmalıdır/ } \\
\text { Doğru }\end{array}$ & 75 & 36,2 & 18 & 8,7 & 93 & 44,9 \\
\hline & Normal saç yağ dengesi için saçlar haftada iki kez yıkanmalıdır & 43 & 20,8 & 7 & 3,4 & 50 & 24,2 \\
\hline \multirow{4}{*}{$\begin{array}{l}\text { Kulak } \\
\text { temizliği } \\
\text { için doğru } \\
\text { uygulama } \\
\text { hangisidir }\end{array}$} & $\begin{array}{l}\text { Düzenli olarak nemli bir bez ile dış kulak ve kulak arkası } \\
\text { temizlenmelidir/ Doğru }\end{array}$ & 56 & 27,1 & 10 & 4,8 & 66 & 31,9 \\
\hline & Düzenli olarak nemli bir bez ile dış kulak ve iç kulak temizlenmelidir & 33 & 15,9 & 8 & 3,9 & 41 & 19,8 \\
\hline & $\begin{array}{l}\text { Ara sıra dış kulak yolunda biriken kir ucu sivri bir cisimle } \\
\text { çıartılmalıdır }\end{array}$ & 11 & 5,3 & 4 & 1,9 & 15 & 7,2 \\
\hline & Kulak içi ucuna pamuk sarılı çubuk ile sık sık temizlenmelidir & 72 & 34,8 & 13 & 6,3 & 85 & 41,1 \\
\hline \multirow{4}{*}{$\begin{array}{l}\text { Burun } \\
\text { temizliği } \\
\text { için doğru } \\
\text { uygulama } \\
\text { hangisidir? }\end{array}$} & Burun deliklerine serum fizyolojik çekilerek temizlenmelidir. & 30 & 14,5 & 1 & 0,5 & 31 & 15,0 \\
\hline & $\begin{array}{l}\begin{array}{l}\text { Akarsu veya mendil ile burun atıları sümkürerek } \\
\text { temizlenmelidir./Doğru }\end{array} \\
\end{array}$ & 111 & 53,6 & 24 & 11,6 & 135 & 65,2 \\
\hline & Sadece banyodan sonra burun atıkları mendil ile temizlenmelidir. & 21 & 10,1 & 9 & 4,3 & 30 & 14,5 \\
\hline & Burun delikleri yabancı bir cisim ile karıştırılarak temizlenmelidir. & 10 & 4,8 & 1 & 0,5 & 11 & 5,3 \\
\hline \multirow{3}{*}{$\begin{array}{l}\text { Diş sağlığ1 } \\
\text { için doğru } \\
\text { uygulama } \\
\text { hangisidir }\end{array}$} & Yemeklerden sonra ağız sadece su ile çalkalanmalıdır. & 23 & 11,1 & 10 & 4,8 & 33 & 15,9 \\
\hline & Yemeklerden sonra çiklet çiğnenmelidir. & 10 & 4,8 & - & - & 10 & 4,8 \\
\hline & $\begin{array}{l}\text { Yemeklerden sonra dişler fırçalanmalı ve diş araları diş ipi ile } \\
\text { temizlenmelidir. / Doğru }\end{array}$ & 127 & 61,4 & 24 & 11,6 & 151 & 72,9 \\
\hline \multirow{4}{*}{$\begin{array}{l}\text { Doğru el } \\
\text { yıkama } \\
\text { yöntemi } \\
\text { hangisidir? }\end{array}$} & $\begin{array}{l}\text { Ellerin yalnız su ile parmak araları ovuşturularak yıkanması } \\
\text { yeterlidir. }\end{array}$ & 22 & 10,6 & 7 & 3,4 & 29 & 14,0 \\
\hline & $\begin{array}{l}\text { Eller bilek hizasından itibaren, alkollü bir çözelti ile parmak araları } \\
\text { ovuşturularak yıkanmalıdır. }\end{array}$ & 27 & 13,0 & 5 & 2,4 & 32 & 15,5 \\
\hline & $\begin{array}{l}\text { Yalnız su ile her iş öncesi ve sonrasında } 15-20 \text { saniye süre ile eller } \\
\text { yıkanmalıdır. }\end{array}$ & 19 & 9,2 & 6 & 17,1 & 25 & 12,1 \\
\hline & $\begin{array}{l}\text { Eller bilek hizasından itibaren, sıcak su ve sabunla parmak araları } \\
\text { ovuşturularak yıkanmalıdır. / Doğru }\end{array}$ & 104 & 50,2 & 17 & 8,2 & 121 & $\mathbf{5 8 , 5}$ \\
\hline \multirow{4}{*}{$\begin{array}{l}\text { Ayak } \\
\text { temizliği } \\
\text { için en } \\
\text { doğru } \\
\text { uygulama } \\
\text { hangisidir? }\end{array}$} & $\begin{array}{l}\text { Ayaklar her gün sadece su ile yıkanmalı, kurulanmalı ve parmak } \\
\text { aralarına nemlendiricili krem sürülmelidir. }\end{array}$ & 48 & 23,2 & 11 & 5,3 & 59 & 28,5 \\
\hline & Ayaklar her gün sadece su ile yıkanmalı ve kurulanmalıdır. & 52 & 25,1 & 6 & 2,9 & 58 & 28,0 \\
\hline & Ayaklar iki, üç günde bir su ve sabunla yıkanıp kurulanmalıdır. & 17 & 8,2 & 1 & 0,5 & 18 & 8,7 \\
\hline & $\begin{array}{l}\text { Ayaklar her gün sadece su il iki-üç günde bir de su ve sabunla } \\
\text { yıkanmalı ve kurulanmalıdır. / Doğru }\end{array}$ & 55 & 26,6 & 17 & 8,2 & 72 & $\mathbf{3 4 , 8}$ \\
\hline \multirow{4}{*}{$\begin{array}{l}\text { Ayakkabı } \\
\text { ile ilgili } \\
\text { yanlış bilgi } \\
\text { hangisidir? }\end{array}$} & Ayakkabı topuğunun yüksekliği 3 cm' i geçmemelidir & 34 & 16,4 & 11 & 5,3 & 45 & 21,7 \\
\hline & $\begin{array}{l}\text { Ayakkabının ucu ile başparmak arasında en az } 1 \mathrm{~cm}^{\prime} \text { lik mesafe } \\
\text { olmalıdır }\end{array}$ & 35 & 16,9 & 6 & 2,9 & 41 & 19,8 \\
\hline & $\begin{array}{l}\text { Ayak topuğu, ayakkabının içinde rahatlıkla aşağı yukarı hareket } \\
\text { edebilmelidir. / Doğru }\end{array}$ & 50 & 24,2 & 14 & 6,8 & 64 & 30,9 \\
\hline & Ayakkabının iç kenarı kavisli olmalıdır & 53 & 25,6 & 4 & 1,9 & 57 & 27,5 \\
\hline \multirow{4}{*}{$\begin{array}{l}\text { Doğru el } \\
\text { ve ayak } \\
\text { tırnaklarını } \\
\text { n kesim } \\
\text { şekli } \\
\text { hangisidir? }\end{array}$} & Her ikisi de düz şekilde kesilmelidir & 49 & 23,7 & 6 & 2,9 & 55 & 26,6 \\
\hline & Her ikisi de oval şekilde kesilmelidir & 52 & 25,1 & 9 & 4,3 & 61 & 29, \\
\hline & El tırnakları oval, ayak tırnakları düz şekilde kesilmelidir. / Doğru & 50 & 24,2 & 15 & 7,2 & 65 & 31,4 \\
\hline & El tırnakları düz, ayak tırnakları oval şekilde kesilmelidir. & 21 & 10,1 & 5 & 2,4 & 26 & 12,6 \\
\hline
\end{tabular}


Araştırmaya katılan personelin $\% 58,9^{\prime}$ u temizlik açısından vücut banyosunun etkilerini, $\% 58,5^{\prime}$ i temizlik kurallarına uygun el yıkama yöntemini, \%72,9 diş sağlığı, \%65,2' si burun temizliği için doğru uygulamayı bilmesine rağmen; el ve ayak tırnaklarının kesim şeklini, saç ve ayak temizliği için en doğru uygulamayı bilmemektedir. Ayrıca ayakkabı ile ilgili yanlış bilgiye sahip olan çalışan sayısının da yarıdan fazla olduğu saptanmıştır.

\section{SONUÇ ve TARTIŞMA}

Turizm işletmeleri, müşterilerinin beklentilerini karşılayarak kaliteli hizmeti sunmasının yanı sıra sağlık koşullarına uygun ve hijyen kurallarının tam olarak yerine getirmesi hususuna da dikkat etmelidir. Yiyecek içecek hizmeti sunan turizm işletmelerinde hijyen temizliğin en önemli unsuru personeldir. Personelin sağlık durumu, kılık kıyafeti, hijyen bilgisi, hijyen uygulamaları ve hijyen alışkanlıkları gıda işlemeye ve sunmaya uygun olmak zorundadır. Bu nedenle personelin hijyen bilgisinin güncel olması ve sürekli denetlenmesi gerekmektedir.

Şanlıurfa'da faaliyet gösteren konaklama işletmelerinde çalışan personelin hijyen bilgisi ve uygulamalarını tespit etmek amacıyla yapılan bu araştırmada elde edilen sonuçlar doğrultusunda; Araştırmaya katılan personelin $\% 58,9^{\prime} u$ temizlik açısından vücut banyosunun etkilerini, \%58,5' i temizlik kurallarına uygun el yıkama yöntemini, \%72,9 diş sağlığını, \%65,2' si burun temizliği için doğru uygulamayı bilmesine rağmen; el ve ayak tırnaklarının kesim şeklini, saç ve ayak temizliği için en doğru uygulamayı bilmemektedir. Ayrıca ayakkabı ile ilgili yanlış bilgiye sahip olan çalışan sayısının da yarıdan fazla olduğu saptanmıştır. Personelin diş hekimine gitme nedenlerine bakıldığında, büyük çoğunluğunun ağız kokusu ve tedavi kaynaklı olduğu görülürken, personelin çoğunluğunun genel kontrol için değil de mecburiyetten dolayı diş hekimine gittiği tespit edilmiştir. Bu sonuç Yıldırım (2014)'ın çalışmasının sonuçları ile tutarlılık göstermektedir.

Personelin el yıkama durumları ile cinsiyetleri arasında ilişkiye bakıldığında, burun ve ağız gibi bölgelere dokunduktan sonra, sigara içtikten sonra ellerini yıkadığını belirten personel arasında istatistiksel olarak anlamlı bir farkın olduğu saptanmıştır. Bu sonuç Turan (2009)'ın çalışmasının sonuçları ile tutarlılık gösterirken, Cavalli vd., (2016)'ın çalışmasının sonuçları ile tutarlılık göstermemektedir. Personelin bireysel havlu kullanmanın önemi konusunda yetersiz bilgiye sahip oldukları, bunun yanında kolaylığı bakımından ortak havlu kullanıldığı düşünülmektedir.

Personelin kişisel eşyalarını bireysel ya da ortak kullanma durumları ile cinsiyetleri arasındaki ilişkiye bakıldığında, el havlusu bireysel ve ortak kullanımı ile personel oranları arasında istatistiksel olarak anlamlı bir farkın olduğu saptanmıştır. Bu sonuç Kızılcık (2016)'ın çalışmasının sonuçları ile tutarlılık göstermektedir.

Yine araştırma kapsamında çalışanların hijyen bilgi düzeyleri ile hijyen uygulamaları arasında bir farklılığın olduğu tespit edilmiştir. Personelin büyük bir kısmının hijyen konusunda hiç eğitim almadığı, eğitim alanların ise tam olarak uygulamadığı görülmüştür. Bu sonuç Baş ve Sağlam (1997), Ural (2007), Annor ve Baiden (2011), Huang vd. (2012), çalışmalarının sonuçları ile tutarlılık gösterdiği tespit edilmiştir.

Yiyecek içecek işletmelerinde gıda güvenliği ile ilgili uygulamaların artırılması ve daha kaliteli bir hizmet sunulabilmesi için aşağıdaki önerilerin yarar sağlayacağı düşünülmektedir:

- İlgili kamu kurumları ve STK'lar tarafından gerekli denetimler titizlikle ve daha sık periyotlarda yapilmall, 
- Yiyecek içecek işletme sahipleri ve çalışanları hijyen ve gıda güvenliğinin önemi hakkında bilgilendirilerek gerekli eğitimlerin düzenli olarak yapılması sağlanmalı,

- İşletmeler tarafından da düzenli aralıklarla çalışan personele hizmet içi eğitim verilmeli,

- Personelin hijyen ve gıda güvenliğine yönelik bilgilerini uygulamaya geçirilebilmesi için uygun çalışma şartları işletmeler tarafından oluşturulmalı,

- Konaklama işletmelerinde çalışan personelin kişisel hijyen konusunda bilgi ve uygulamalarının yükseltilmesine yönelik gerekli önlemlerin alınması, bunu da en üst yöneticiden başlayarak bütün kadronun hijyeni bir işletme vizyonu kabul ederek üretimden sunuma kadar hizmetin bütün aşamalarında uygulamaları sağlanmalıdır.

\section{KAYNAKÇA}

Angellillo, I.F., Viggiani, N. M., Greco, R.M. and Rito, D. (2001). Haccp and Food Hygiene in Hospital: Knowledge, Attitudes, and Practices of Foodservices Staff in Calabria, Infection Control and Hospital Epidemiology, 1(22),6.

Annor, G.A and Baiden, E.A. (2011). Evaluation of Food Hygiene Knowledge Attitudes and Practices of Food Handlers in Food Businesses in Accra, Food and Nutrition Sciences, 2, 830-836.

Ayaz, N. ve Aydın, A. (2017). Turizmde Gıda Güvenliği Sürecinde Hijyen Davranışı Üzerine Bir Araştırma. Güncel Turizm Araştırmaları Dergisi, 1(2), 136- 150.

Baş, M. ve Sağlam, F. (1997). Otel Beslenme Servis Personelinin Kişisel ve Çevre Hijyen Bilgisinin Ölçülmesi, Beslenme ve Diyet Dergisi 26(1), 28-32.

Beyhan, Y. ve Ersin, M. (2001). Toplu Beslenme Sistemlerinde Hijyen Sanitasyonu Sağlama Önerileri, Türk Tabipleri Birliği Mesleki Sağllk ve Güvenlik Dergisi, Ekim, 2(8), 19-26.

Can, S. (2008). Küçük Ölçekli Otel İşletmelerinin Mutfak Departmanlarında Çalışan Personelin Hijyen ve Sanitasyon Alışkanlıkları (Erdek Yöresinde Bir Uygulama), Yayınlanmış Yüksek Lisans Tezi, Balıkesir Üniversitesi Sosyal Bilimler Enstitüsü Turizm İşletmeciliği ve Otelcilik Anabilim Dalı, Balıkesir.

Cavalli, S.B., Cortese, R.D.M., Feldman, C. and Verios, M.B. (2016). Food safety and hygiene practices of vendors during the chain of Street food production in Florianopolis, Brazil: A crosssectional study. Food Control, 62, 178-186.

Cömert, M. (2007). Tehlike Analizi Kritik Kontrol Noktaları Sisteminin Planlama ve Uygulaması: Ankara'da Beş Yıldızlı Otel İşletmelerinde Araştırma. Yayınlanmış Yüksek Lisans Tezi, Gazi Üniversitesi Eğitim Bilimleri Enstitüsü Turizm İşletmeciliği Eğitimi Bilim Dalı, Ankara.

Cömert, M. (2011). Otel İşletmeleri Mutfak Personelinin Gıda Güvenliği Algılamaları ve Ankara'da Bir Uygulama. Yayınlanmış Doktora Tezi, Gazi Üniversitesi, Eğitim Bilimleri Enstitüsü Turizm İşletmeciliği Eğitimi Ana Bilim Dalı, Turizm Eğitimi Bilim Dalı, Ankara.

Cömert, M. ve Özel, K. (2015). Otel İşletmelerinde Hijyen ve Sanitasyon Kurallarının Mutfak Personeli Tarafından Bilinirlik ve Uygulanma Düzeyi, Akademik Sosyal Araştırmalar Dergisi, 3(16), 310-322.

Cömert, M. ve Ünlüönen, K. (2013). Otel İşletmeleri Mutfak Çalışanlarının Personel Hijyeni Bilgi Düzeylerinin Belirlenmesi, Journal of Tourism and Gastronomy Studies 1/1 (2013) 3-12. 
Coştan, D. (2012). İlköğretim Birinci Sını Öğrencilerine Verilen Planlı El Yıkama Eğitiminin El Yıkama Davranışı Üzerine Etkisinin Belirlenmesi, Yayınlanmış Yüksek Lisans Tezi, Başkent Üniversitesi Sağlık Bilimleri Enstitüsü, Ankara.

Çetiner, H. (2010). Yiyecek-İçecek İşletmelerinde Hijyen, Sanitasyon ve Personelin Hijyen Kurallarına İlişkin Davranışlarında Ĕ̆itim Faktörü, Yayınlanmış Yüksek Lisans Tezi, Gazi Üniversitesi, Eğitim Bilimleri Enstitüsü, Turizm İşletmeciliği Eğitimi Anabilim Dalı, Ankara.

Çil, B., Şanlıer, N., Başer, F. ve Abubakirova, A. (2017). Türkiye'deki otel personelinin tutum ve davranışları Gıda güvenliği bilgisi arasındaki ilişkinin yapısal modellemesi, Food Control 73, 438444 .

Dere, H. (2018). Toplu Beslenme Sistemlerinde Mutfak Personeline Verilen Hijyen Eğitiminin Mutfağın Hijyen Durumuna Etkisi. Yayınlanmış Yüksek Lisans Tezi, Başkent Üniversitesi, Sağlık Bilimleri Enstitüsü, Beslenme ve Diyetetik Anabilim Dalı, Ankara.

Gül, K., Gül, G. ve Saatçi, G. (2018). Konaklama Sektöründe Hijyen Kaynaklı Müşteri Sağlık Riski Algısı: Bursa ve Diyarbakır'daki Tesislere Yönelik Kıyaslama. Seyahat ve Otel İşletmeciliği Dergisi, $15(1), 23-37$.

Güner, M. (2007). Toplu Beslenme Hizmeti Veren Kurum Mutfaklarının Hijyen ve Sanitasyon Durumlarının Değerlendirilmesi, Yayınlanmış Yüksek Lisans Tezi, Gazi Üniversitesi Aile Ekonomisi ve Beslenme Eğitimi Ana Bilim Dalı, Ankara.

Huang, K.W., Sun, Y.M. and Wang, S.T. (2012). Hygiene knowledge and practices of night market food vendors in Tainan City, Taiwan, Food Control, 23, 159-164

Kabacık, M. (2013). Dört ve Beş Yıldızlı Otel Mutfaklarında Çalışan Mutfak Personelinin Gıda Güvenliği Konusunda Bilgi Düzeylerinin Saptanması, Ordu Üniversitesi Sosyal Bilimler Enstitüsü Dergisi, $10-12,112-120$.

Kahveci, G. ve Demirtaş, Z. (2012). İlköğretim Okulu 6. 7. ve 8. Sınıf Öğrencilerinin Temizlik ve Hijyen Algıları. Pegem Ĕgitim ve Öğretim Dergisi, 2(2), 51-61.

Kayalı, F. (2013). Toplu Beslenme Hizmeti Veren Bir Kurum Mutfağı ve Personelinin Hijyen Yönünden Değerlendirilmesi ve Beslenme Durumlarının Saptanması, Yayınlanmış Yüksek Lisans Tezi, Hacettepe Üniversitesi Sağlık Bilimleri Enstitüsü Toplu Beslenme Sistemleri Programı, Ankara.

Kızılcık, O. (2016). Turizme Hizmet Sunan Pastane İşletmelerinde Çalışan Geleneksel Maraş Dondurması Üretim Personelinin Hijyen ve Gıda Güvenliğine İlişkin Bilgi ve Uygulama Düzeyi Üzerine Bir Araştırma, Yayınlanmış Yüksek Lisans Tezi, Gaziantep Üniversitesi, Sosyal Bilimler Enstitüsü Turizm İşletmeciliği Ana Bilim Dalı, Gaziantep.

Kurt, M. (2018). Kapadokya Bölgesi Otel Mutfaklarında Çalışanların Mutfak Hijyen Durumları Üzerine Görüşleri, Yayınlanmış Yüksek Lisans Tezi, Gazi Üniversitesi Eğitim Bilimleri Enstitüsü Aile Ekonomisi ve Beslenme Eğitimi Ana Bilim Dalı, Ankara.

Odo, A.N and Onoh, S.C. (2018). Food Hygiene Knowledge and Practices among Food Handlers in University of Nigeria, Nsukka Campus, Mediterranean Journal of Social Sciences, 9(6), 137-144.

Sargın, Y. (2005). Ankara'daki Dört ve Beş Yıldızh Otellerde Çalışan Yiyecek ve İçecek Personelinin Hijyen Bilgileri ve Uygulamalarının İncelenmesi, Yayınlanmış Yüksek Lisans Tezi, Ankara Üniversitesi Fen Bilimleri Enstitüsü Ev Ekonomisi (Beslenme Bilimleri) Anabilim Dalı, Ankara. 
Soner, A. ve Özgen, I. (2002) Yiyecek-içecek işletmelerinde uluslararası hijyen standartları Turizmde Sağlık ve Beslenme; Sorunlar ve Çözümler Sempozyumu Bildiriler Kitabı, Başkent Üniversitesi, Mayıs 2002. Alanya. ss:53-54.

Şanlıer, N., Çil, B., Başer, F. ve Abubakirova, A. (2016). 4-5 Yıldızlı Otellerdeki Servis ve Mutfak Personellerinin Gıda Güvenliğine İlişkin Bilgi, Tutum ve Davranışları: Türkiye ve Kazakistan Karşılaştırması, Seyahat ve Otel İşletmeciliğ̈i Dergisi 13 (3), 23-37.

Şanlıer, N. ve Tunç Hussein, A. (2008). Yiyecek - İçecek hizmeti veren otel mutfakları ve personelinin hijyen yönünden değerlendirilmesi: Ankara Örneği, Kastamonu Ĕ̆itim Dergisi, 16(2), 461-468.

Şimşek, A. Ç. (2006). On birinci Sınıf Öğrencilerinin Kişisel Bakım ve Sağhı̆̆ın Korunmasına Yönelik Davranışlarının İncelenmesi (Üç Lise Örneği- Ankara), Yayınlanmış Tezsiz Yüksek Lisans Dönem Projesi, Ankara Üniversitesi Sağlık Bilimleri Enstitüsü, Ankara.

Tartaç, Y. (2007). Kız Meslek Liselerinde Kişisel Hijyenle İlgili Alışkanlıkların Belirlenmesi ve Yapılan Eğitim Sonrası Ĕ̆itimin Etkinliğinin Değerlendirilmesi, Yayınlanmış Yüksek Lisans Tezi, Gazi Üniversitesi Sağlık Bilimleri Enstitüsü, Ankara.

Tayar, M. (2011). Hijyen ve Sanitasyon. Eskişehir: Anadolu Üniversitesi, Açık öğretim Fakültesi Yayınları.

Turan, İ. (2009). Mutfak Personelinin El Hijyeni Bilgisi ve Uygulamalarının İncelenmesi, Yüksek Lisans Tezi, Ankara Üniversitesi Fen Bilimleri Enstitüsü Ev Ekonomisi (Beslenme Bilimleri) Anabilim Dalı, Ankara.

Ural, D. (2007). Konaklama İşletmelerinde Çalışan Personelin Kişisel Hijyen Bilgileri ve Uygulamaları Üzerine Bir Araştırma, Yüksek Lisans Tezi, Gazi Üniversitesi Eğitim Bilimleri Enstitüsü Aile Ekonomisi ve Beslenme Eğitimi Anabilim Dall, Ankara.

Uyanık, A. (2006). Afyonkarahisar Sandıklı Hüdai Kaplıcalarının Hijyenik Koşulları ile Kaplıca Personelinin Bilgi Tutum ve Davranışları, Yayınlanmış Yüksek Lisans Tezi, Süleyman Demirel Üniversitesi Sağlık Bilimleri Enstitüsü Tıp Fakültesi Halk Sağlığı Anabilim Dalı, Isparta.

Uzunçakmak, T. (2012) Ergenlerde Öz Bakım Eğitiminin Öz Bakım Gücüne Etkisi, Yayınlanmış Yüksek Lisans Tezi, Erciyes Üniversitesi Sağlık Bilimleri Enstitüsü, Kayseri.

Üzücü, A. (2015). Toplu Beslenme Hizmeti Veren Kurumlarda Besin ve Personel Hijyeni Bilgi Düzeyi ve Davranışları Üzerine Bir Araştırma (Kayseri İl Örneği), Yayınlanmış Yüksek Lisans Tezi, Selçuk Üniversitesi Sosyal Bilimler Enstitüsü Çocuk Gelişimi ve Ev Yönetimi Eğitimi Anabilim Dalı, Beslenme Eğitimi Bilim Dalı, Konya.

World Health Organization, https://www.who.int/topics/hygiene/en/ [Erişim Tarihi: 03.06.2021].

Yalçın, H. ve Özkalp, B. (2005). Vücut Hijyeninin Önemi ve Yara Bakımında Yeni Gelişmeler, Ulusal Sterilizasyon Dezenfeksiyon Kongresi, On dokuz Mayıs Üniversitesi 20-24 Nisan 2005. Samsun. ss:287-308.

Yasan, Z. (2007). Gıda Sektöründe HACCP Uygulaması ve Çevreyle Etkileşimi. Gazi Üniversitesi, Fen Bilimleri Enstitüsü, Ankara.

Yıldırım, E. (2014). Konaklama İşletmelerinde Mutfak ve Servis Personelinin İş Tatmini ile Kişisel Hijyen Bilgi ve Uygulamaları, Yayınlanmış Yüksek Lisans Tezi, Gazi Üniversitesi Eğitim Bilimleri Enstitüsü Aile Ekonomisi ve Beslenme Eğitimi Anabilim Dalı, Ankara. 
Yılmaz Irmak, H. (2015). Hastanede Yatan Hastaların Kişisel Hijyen ile İlgili Bilgi Tutum ve Davranışlarının Değerlendirilmesi, Yayınlanmış Yüksek Lisans Tezi, Cumhuriyet Üniversitesi Sağlık Bilimleri Enstitüsü, Sivas. 